\title{
Optimasi dan Validasi Metode KCKT untuk Identifikasi dan Penetapan Kadar Metabolit Nitrofuran dalam Bakso Udang
}

\section{The HPLC Methods for Identificaton and Determination of Nitrofuran Metabolite Levels in Shrimps Meatballs}

Rachma Ayuningtyas ${ }^{1}$, Riesta Primaharinastiti ${ }^{2}$, Mochammad Yuwono ${ }^{2 *}$

${ }^{1}$ Balai Besar Pengawas Obat dan Makanan (BBPOM) di Surabaya, Surabaya, Indonesia

${ }^{2}$ Departemen Ilmu Kefarmasian, Fakultas Farmasi, Universitas Airlangga, Surabaya, Indonesia

*Corresponding author: yuwono05@yahoo.com

Submitted: 4 Agustus 2020

Accepted: 15 September 2020

Published: 29 Agustus 2021

\begin{abstract}
Background: Furazolidone, furaltadone, and nitrofurantoin are nitrofuran antibiotics still illegally used as food additives in shrimp farming and other food-producing animals. Therefore, due to their carcinogenicity, it is needed to control the contamination of nitrofuran metabolites in food products containing shrimps as the main ingredient. Objective: This study aimed to validate the HPLC method for determining levels of nitrofuran metabolites in shrimp meatballs. Methods: Furazolidone, furaltadone and nitrofurantoin were derivatized with 2nitrobenzaldehyde, extracted into ethyl acetate, washed with hexane, and applied to HPLC with UV-PDA detector. The separation was performed on C-18 column $46 \times 250 \mathrm{~mm}, 5 \mu \mathrm{m}$ using the mobile phase of $20 \mathrm{mM}$ ammonium acetate and acetonitrile (70:30), with a $0.5 \mathrm{~mL} / \mathrm{min}$ flow rate column temperature of $40^{\circ} \mathrm{C}$, injection volume of $100 \mu \mathrm{L}$. Results: The method showed good separation of metabolites and other interferences with an analysis time of 40 minutes, resulting in good linear response in the concentration ranges of $51.90-103.79 \mathrm{ng} / \mathrm{mL}$ (AOZ); 56.63 - $101.39 \mathrm{ng} / \mathrm{mL}$ (AMOZ); dan 49.92 - $89.86 \mathrm{ng} / \mathrm{mL}$ (AHD). The accuracy was found to be 78.50 - $102.29 \%$ for AOZ; 77.02 - 99.87\% for AMOZ; and 85.54 - 99.77\% for AHD; whereas the precision (RSD) for the repeatability test was 6.10 - 19.90\%; 3.68 - 17.75\%; and 2.75 - 12.58\% for AOZ, AMOZ and AHD. LOD and LOQ obtained were between 3.09 and $10.29 \mathrm{ng} / \mathrm{mL}$ (AOZ); 6.84 and $22.82 \mathrm{ng} / \mathrm{mL}$ (AMOZ); and 4.61 and $15.36 \mathrm{ng} / \mathrm{mL}$ (AHD). Conclusion: The proposed method can detect and quantify nitrofuran metabolite contamination in shrimp meatballs.
\end{abstract}

Keywords: AHD, AMOZ, AOZ, high-performance liquid chromatography, nitrofuran

\begin{abstract}
Abstrak
Pendahuluan: Dikarenakan sifat dari Furazolidon, furaltadon, dan nitrofurantoin yang karsinogenik, perlu dilakukan pengawasan terhadap cemaran metabolit nitrofuran dalam produk berbahan dasar udang. Nitrofuran dimetabolisme secara cepat dalam jaringan tubuh hewan. Tujuan: Penelitian ini bertujuan melakukan validasi metode KCKT untuk penetapan kadar metabolit nitrofuran dalam bakso udang. Metode: Metabolit furazolidone, furaltadone dan nitrofurantoin yaitu 3-amino-2-oxazolidinone (AOZ), 3-amino-5-methylmorpholino-2oxazolidinone (AMOZ), dan 1-aminohydantoin (AHD) diderivatisasi menggunakan 2-nitrobenzaldehida, diekstraksi dalam etil asetat dan dicuci dengan n-heksana, kemudian disuntikkan ke dalam system KCKT dengan detektor UV-PDA. Pemisahan dilakukan dengan kolom C-18 46 x $250 \mathrm{~mm}, 5 \mu \mathrm{m}$. Sebagai fase gerak adalah ammonium asetat $20 \mathrm{mM}$ : asetonitril (70:30), dengan laju alir $0.5 \mathrm{~mL} / \mathrm{menit}$, suhu kolom $40^{\circ} \mathrm{C}$, dan volume injeksi $100 \mu \mathrm{L}$. Hasil: Metode yang digunakan dapat memisahkan semua metabolit dari senyawa pengotor dengan waktu analisis 40 menit, dan menghasilkan linieritas yang baik dalam rentang konsentrasi 51,90 - 103,79 ng/mL (AOZ); 56,63 - 101,39 ng/mL (AMOZ); dan 49,92 - 89,86 ng/mL (AHD). Akurasi metode dipresentasikan sebagai rekoveri dengan hasil sebesar 78,50 - 102,29\% untuk AOZ; 77,02 - 99,87\% untuk AMOZ; and 85,54 - 99,77\% untuk AHD. Presisi metode dinyatakan dalam simpangan baku relatif (relative standard deviation, RSD) dengan hasil masing-
\end{abstract}


masing adalah 6,10 - 19,90\%; 3,68 - 17,75\%; and 2,75 - 12,58\% untuk AOZ, AMOZ, dan AHD. LOD dan LOQ sebesar 3,09 ng/mL dan 10,29 ng/mL (AOZ); 6,84 ng/mL dan 22,82 ng/mL (AMOZ); serta 4,61 ng/mL dan 15,36 $\mathrm{ng} / \mathrm{mL}$ (AHD). Kesimpulan: Metode uji dapat digunakan untuk skrining awal untuk mendeteksi dan penetapan kadar cemaran metabolit nitrofuran pada bakso udang.

Kata kunci: AHD, AMOZ, AOZ, kromatografi cair kinerja tinggi, metabolit

\section{PENDAHULUAN}

Nitrofuran adalah golongan antibiotik yang seringkali digunakan sebagai bahan tambahan pakan pada budidaya udang. Penggunaan nitrofuran untuk ternak telah dilarang di negara-negara seperti Australia, AS, Filipina, Thailand dan Brasil (Khong dkk., 2004). Namun pada tahun 2007 Rapid Alert System for Food and Feed (RASFF) Uni Eropa menemukan adanya kandungan metabolit nitrofuran yaitu 3-amino-2oxazolidinone (AOZ) pada udang masak yang dibekukan, yang diekspor dari Indonesia ke Belgia (European Comission, 2007). Hal ini menunjukkan bahwa antibiotika golongan nitrofuran masih banyak digunakan, walaupun telah dilarang. Di Indonesia, menurut Peraturan Menteri Kelautan dan Perikanan Republik Indonesia nomor 39/PERMEN-KP/2015 tentang Pengendalian Residu Obat Ikan, Bahan Kimia, dan Kontaminan pada Kegiatan Pembudidayaan Ikan Konsumsi, batas minimum kerja laboratorium (BMKL) metabolit nitrofuran dalam ikan dan udang adalah $1 \mu \mathrm{g} / \mathrm{Kg}$. Oleh karena itu diperlukan adanya pengawasan terhadap cemaran metabolit nitrofuran dalam produkproduk dengan komposisi utama udang.

Beberapa obat golongan nitrofuran yang umum digunakan adalah furazolidon, furaltadon, dan nitrofurantoin. Golongan ini dimetabolisme secara cepat dalam tubuh hewan dan umumnya tidak muncul sebagai residu, sehingga menyulitkan deteksinya dalam produk makanan yang berasal dari hewan. Ketiga senyawa nitrofuran tersebut ternyata mampu membentuk metabolit toksik, yaitu 3-amino-2-oxazolidinone (AOZ) dari furazolidon, 3-amino-5-methylmorpholino-2oxazolidinone (AMOZ) dari furaltadon, dan 1aminohydantoin (AHD) dari nitrofurantoin (Vass dkk., 2008). Rumus struktur furazolidon, furaltadon, nitrofurantoin, dan masing-masing metabolitnya dapat dilihat pada Gambar 1. Metabolit ini dapat terikat di jaringan dan stabil untuk waktu yang lama, sehingga berfungsi sebagai penanda untuk penggunaan nitrofuran secara ilegal pada hewan penghasil makanan (Vass dkk., 2008). Hidrolisis dengan asam adalah metode yang umum digunakan untuk memecah ikatan antara metabolit dengan protein (Verdon dkk., 2007), dan derivatisasi dengan nitrobenzaldehida dilakukan untuk meningkatkan sensitivitasnya pada metode kromatografi cair (Kaufmann dkk., 2015).

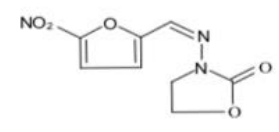

(a)

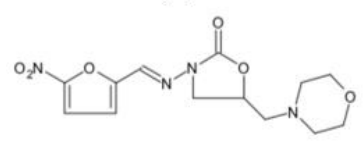

(c)

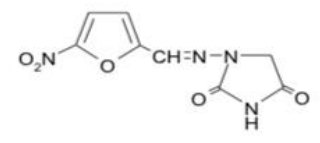

(e)

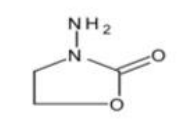

(b)

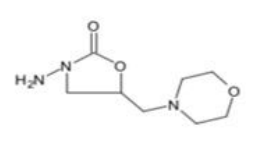

(d)

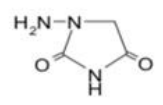

(f)
Gambar 1. Rumus struktur senyawa golongan nitrofuran dan metabolitnya: (a) furazolidon; (b) 3amino-2-oxazolidinone (AOZ); (c) furaltadon; (d) 3amino-5-methylmorpholino-2-oxazolidinone (AMOZ);

(e) nitrofurantoin; (f) 1-aminohydantoin (AHD)

(Vass dkk., 2008)

Metode yang telah digunakan untuk analisis kadar metabolit nitrofuran adalah Enzyme Linked Immunosorbent Assay (ELISA). ELISA adalah metode analisis kuantitatif yang menunjukkan reaksi antigenantibodi melalui perubahan warna yang diperoleh dengan menggunakan konjugat dan enzim substrat enzim, yang berfungsi untuk mengidentifikasi keberadaan dan konsentrasi molekul dalam sampel biologis (Aydin, 2015). Karena sifatnya yang menggunakan antibodi yang spesifik untuk analit target, metode ini tidak dapat digunakan untuk melakukan penetapan kadar beberapa analit secara simultan.

Metode kromatografi cair kinerja tinggi dengan detektor tandem spektrometri massa (HPLC-MS/MS) semakin banyak digunakan dan telah secara signifikan meningkatkan validitas metode kuantitatif untuk penentuan metabolit nitrofuran dalam beberapa tahun terakhir (Verdon dkk., 2007). Metode LC-MS/MS memiliki selektivitas dan sensitivitas yang sangat tinggi, namun aplikasinya masih sangat mahal dan tidak semua 
laboratorium pengujian memiliki instrumen ini. Untuk keperluan kontrol kualitas secara rutin terhadap sampel produk pangan yang jumlahnya cukup banyak, maka diperlukan suatu metode skrining sebagai metode awal sebelum dilakukan metode LC-MS/MS. Dengan demikian LC-MS/MS lebih ditujukan untuk keperluan konfirmasi terhadap sampel yang dinyatakan positif pada hasil metode skrining.

Metode lain yang digunakan untuk penentuan kadar metabolit nitrofuran adalah kromatografi cair kinerja tinggi (KCKT) dengan detektor UV-PDA atau UV, antara lain yang telah dilakukan oleh Prihanani, dkk. (2017) yaitu analisis AOZ pada hati dan otot dada ayam. Baru-baru ini, Fernando dkk. (2017) menggunakan KCKT dengan detektor photodiode array (PDA) untuk analisis metabolit nitrofuran dalam udang, dan memperoleh hasil rerata rekoveri untuk AOZ, AMOZ, semikarbazida (SEM), dan AHD masing-masing adalah $107 \%, 107 \%, 115 \%$, dan $114 \%$. Namun sejauh ini belum tersedia metode skrining yang sudah tervalidasi untuk penentuan kadar metabolit nitrofuran pada pangan olahan yang berbahan dasar udang, misalnya bakso udang. Pada penelitian-penelitian terdahulu untuk validasi metode analisis metabolit nitrofuran, digunakan bahan baku udang segar. Sedangkan sejauh ini belum ada penelitian yang menggunakan sampel pangan olahan udang. Tujuan dari penelitian ini adalah melakukan optimasi dan validasi metode KCKT dengan detektor UV-PDA sebagai metode awal untuk identifikasi dan penetapan kadar residu metabolit nitrofuran dalam bakso udang.

\section{BAHAN DAN METODE}

\section{Bahan}

Certified Reference Material AOZ Vetranal ${ }^{\mathrm{TM}}$ (CAS \# 80-65-9), AMOZ Vetranal ${ }^{\mathrm{TM}}$ (CAS \# 43056-639), dan 1-aminohydantoin hidroklorida (AHD, CAS \# 2827-56-7), ketiganya diperoleh dari Sigma-Aldrich; asetonitril derajat KCKT (Merck), metanol derajat KCKT (Merck), 2-nitrobenzaldehid (2-NBA, SigmaAldrich), dimetil sulfoksida pro analysis (Merck), etil asetat pro analysis (Merck), n-heksan pro analysis (Merck), ammonium asetat pro analysis (Merck), dikalium hidrogen fosfat pro analysis (Merck), asam hidroklorida pro analysis 37\% (Merck).

Alat

Sistem KCKT (Shimadzu Prominence) yang dilengkapi detector PDA (SPD 20M), pompa (LC 20 $\mathrm{AD}$ ), degasser (DGU $20 \mathrm{~A}$ ), oven (CTO 20A), dan autosampler (SIL $20 \mathrm{HT}$ ). Kolom C-18 250x46 mm, 5 $\mu \mathrm{m}$ (GL Sciences); waterbath (Memmert WNB 22),

P-ISSN: 2406-9388

E-ISSN: 2580-8303 sentrifuge (Thermo Scientific Megafuge 16), neraca mikro (Sartorius MSA 6 GS), neraca analitik (Mettler Toledo MS 204S).

\section{Metode}

Pembuatan larutan baku induk $(50 \mu \mathrm{g} / \mathrm{mL})$

Ditimbang saksama 2,5 mg masing-masing baku 3amino-2-oxazolidinone (AOZ); 3-amino-5methylmorpholino-2-oxazolidinone (AMOZ); 1aminohydantoin (AHD), dimasukkan masing-masing ke dalam labu tentukur coklat $50,0 \mathrm{~mL}$, masing-masing dilarutkan dan diencerkan dengan metanol hingga tanda.

Pembuatan larutan baku antara tunggal $(1 \mu \mathrm{g} / \mathrm{mL})$

Dipipet 1,0 $\mathrm{mL}$ masing-masing larutan baku induk, dimasukkan ke dalam labu tentukur coklat $50,0 \mathrm{~mL}$ secara terpisah dan diencerkan hingga tanda dengan metanol.

\section{Pembuatan larutan baku antara campuran $(1 \mu \mathrm{g} / \mathrm{mL})$}

Dipipet 5,0 mL masing-masing larutan baku induk, dimasukkan ke dalam labu tentukur coklat $50,0 \mathrm{~mL}$ dan diencerkan hingga tanda dengan metanol sehingga diperoleh larutan baku antara campuran $10 \mu \mathrm{g} / \mathrm{mL}$. Larutan ini kemudian dipipet $1,0 \mathrm{~mL}$, dimasukkan ke dalam labu tentukur coklat $10,0 \mathrm{~mL}$ dan diencerkan dengan metanol hingga tanda.

\section{Pembuatan larutan 2-NBA 50 mM}

Ditimbang $75 \mathrm{mg}$ 2-NBA, dimasukkan ke dalam labu tentukur 10,0 $\mathrm{mL}$, dilarutkan dan diencerkan dengan dimetilsulfoksida hingga tanda.

\section{Pembuatan matriks sampel}

Udang untuk pembuatan matriks sampel merupakan udang ukuran sedang yang diperoleh dari pasar tradisional. Pada analisis yang telah dilakukan sebelumnya, tidak ditemukan adanya cemaran AOZ, AMOZ dan AHD dalam udang yang digunakan. Ditimbang sejumlah udang segar yang telah dikupas dan dibersihkan, kemudian dihaluskan menggunakan food processor. Kemudian dicampur dengan bumbu halus dan tepung tapioka, diaduk hingga merata dan dapat dibentuk. Campuran tersebut lalu dibentuk bulat dengan bantuan dua buah sendok, kemudian direbus pada air panas bersuhu $70^{\circ} \mathrm{C}$ selama \pm 10 menit, dan perebusan dilanjutkan hingga air mendidih $\left(100^{\circ} \mathrm{C}\right)$ dan bakso udang mengapung. Bakso udang yang telah mengapung diangkat dan ditiriskan.

\section{Preparasi larutan matriks sampel}

Larutan matriks sampel dibuat dengan cara menimbang sampel bakso udang yang sudah dihaluskan sejumlah 2,0 g, dimasukkan ke dalam tabung sentrifuga $50 \mathrm{~mL}$. Kemudian ditambahkan $5,0 \mathrm{~mL}$ larutan $\mathrm{HCl}$ $0,1 \mathrm{M}$ dan $200 \mu \mathrm{L}$ 2-NBA 50mM, dikocok hingga 
homogen dengan alat vortex selama 2 menit, diinkubasi selama tidak kurang dari 16 jam pada suhu $37^{\circ} \mathrm{C}$. Setelah derivatisasi, larutan didinginkan pada suhu ruang dan dinetralkan dengan penambahan $1 \mathrm{~mL}$ dikalium hidrogen fosfat $1 \mathrm{M}$, dikocok dengan mixer selama 1 menit, cek pH $7 \pm 0,3$. Kemudian ditambahkan $5 \mathrm{~mL}$ etil asetat dan $3 \mathrm{~mL}$-heksana, dikocok hingga homogen dengan vortex selama 2 menit, kemudian disentrifugasi selama 15 menit pada laju 4000 G. Diambil $6 \mathrm{~mL}$ fase organik dan dimasukkan ke tabung sentrifus lain yang bersih, dikeringkan dengan aliran gas nitrogen dalam waterbath pada suhu $42^{\circ} \mathrm{C}$, kemudian direkonstitusi dengan $2 \mathrm{~mL}$ n-heksana, dikocok hingga homogen dengan alat vortex selama 2 menit. Ditambahkan 4,0 mL metanol:air (5 : 95), dikocok hingga homogen dengan vortex selama 2 menit dan disentrifugasi selama 5 menit pada laju 4000 G. Diambil lapisan bawah menggunakan pipet tetes, disaring dengan syringe filter $0,2 \mu \mathrm{m}$ dan dimasukkan ke dalam vial autosampler. Larutan uji disuntikkan pada sistem KCKT (Alkan dkk., 2016).

\section{Uji selektivitas}

Larutan untuk uji selektivitas dibuat dengan cara cara menimbang sampel bakso udang yang sudah dihaluskan sejumlah 2,0 g, dimasukkan ke dalam tabung sentrifuga $50 \mathrm{~mL}$ dan ditambahkan 0,32 mL larutan baku antara campuran $(1 \mu \mathrm{g} / \mathrm{mL})$. Proses selanjutnya sama dengan pembuatan larutan matriks sampel.

\section{Linieritas, akurasi, dan presisi}

Larutan untuk uji linieritas, akurasi dan presisi dibuat dengan cara menimbang sampel bakso udang sejumlah 2,0 g, dimasukkan ke dalam tabung sentrifuga $50 \mathrm{~mL}$, lalu ditambahkan masing-masing 0,2;0,24; 0,$28 ; 0,32 ; 0,36$; dan $0,4 \mathrm{~mL}$ larutan baku antara campuran $(1 \mu \mathrm{g} / \mathrm{mL})$. Proses selanjutnya sama dengan pembuatan larutan matriks sampel. Untuk uji akurasi, ditambahkan 0,24; 0,32; dan 0,4 mL larutan baku antara campuran $1 \mu \mathrm{g} / \mathrm{mL}$ dan dilakukan replikasi tiga kali, kemudian dihitung persen rekoveri beserta standar deviasinya. Sedangkan untuk uji presisi, digunakan larutan yang sama seperti pada uji akurasi, kemudian dihitung RSD.

\section{LOD-LOQ}

Untuk menentukan LOD, dibuat larutan baku tunggal AOZ, AMOZ dan AHD dalam matriks sampel. Ditimbang sejumlah 2,0 g matriks sampel, dimasukkan ke dalam tabung sentrifuga $50 \mathrm{~mL}$, kemudian ditambahkan 0,16 $\mathrm{mL}$ larutan baku antara tunggal (1 $\mu \mathrm{g} / \mathrm{mL})$. Proses selanjutnya sama dengan pembuatan larutan matriks sampel. Dari kromatogram yang didapat, diukur tinggi puncak analit dan gangguan (noise), kemudian dihitung dengan rumus:

$$
\begin{aligned}
& \mathrm{LOD}=\operatorname{Cs} \frac{3}{\mathrm{~S} / \mathrm{N}} \\
& \mathrm{LOQ}=\operatorname{Cs} \frac{10}{\mathrm{~S} / \mathrm{N}}
\end{aligned}
$$

Dimana:

Cs : konsentrasi baku yang disuntikkan

$\mathrm{S}$ : tinggi puncak analit

$\mathrm{N}$ : tinggi noise

\section{HASIL DAN PEMBAHASAN}

Optimasi kondisi KCKT dilakukan dengan mengacu pada penelitian yang telah dilakukan oleh Aldeek dkk. (2018) dan Alkan dkk. (2016). Kedua metode tersebut menggunakan LC-MS/MS sehingga dalam optimasi metode untuk penelitian ini dilakukan beberapa adaptasi, seperti laju alir. Hasil dari optimasi metode dapat dilihat pada Tabel 1 .

Dari optimasi yang telah dilakukan, didapatkan hasil kondisi KCKT yang optimum untuk memisahkan ketiga senyawa yaitu penyesuaian dari metode yang digunakan oleh Alkan dkk. (2016), dengan fase gerak ammonium asetat $20 \mathrm{mM}$ : asetonitril $(70: 30)$, dengan laju alir $0,5 \mathrm{~mL} / \mathrm{menit}$ dan suhu kolom $40{ }^{\circ} \mathrm{C}$, volume injeksi $100 \mu \mathrm{m}$ dan waktu analisis 40 menit. Detektor PDA digunakan untuk mengetahui panjang gelombang analit, kemudian untuk kuantifikasi digunakan detektor UV. Panjang gelombang analisis yang digunakan adalah $260 \mathrm{~nm}$ 
Tabel 1. Optimasi kondisi KCKT untuk analisis metabolit nitrofuran

\begin{tabular}{|c|c|c|c|c|c|c|}
\hline Penelitian & Pengekstraksi & $\begin{array}{c}\text { Pelarut } \\
\text { rekonstitusi }\end{array}$ & Fase gerak & $\begin{array}{l}\text { Eluasi } \\
\text { kolom }\end{array}$ & Laju alir & Hasil \\
\hline $\begin{array}{l}\text { Aldeek dkk. } \\
\text { (2017) }\end{array}$ & $\begin{array}{l}\text { Etil asetat, } \\
\text { dengan } \\
\text { penambahan } \\
\mathrm{NaCl}\end{array}$ & $\begin{array}{l}\text { Amonium } \\
\text { asetat: } \\
\text { metanol } \\
(20: 80)\end{array}$ & $\begin{array}{c}\mathrm{A}=0,1 \% \text { asam } \\
\text { format dalam air } \\
\mathrm{B}=0,1 \% \text { asam } \\
\text { format dalam } \\
\text { asetonitril }\end{array}$ & Gradien & $0,5 \mathrm{~mL} / \mathrm{min}$ & $\begin{array}{c}\text { Puncak } \\
\text { kromatogram } \\
\text { AOZ dan AHD } \\
\text { tampak pecah } \\
\text { (split peaks) }\end{array}$ \\
\hline $\begin{array}{l}\text { Alkan dkk. } \\
\text { (2016) }\end{array}$ & $\begin{array}{c}5 \mathrm{~mL} \text { etil asetat } \\
+3 \mathrm{~mL} \mathrm{n}- \\
\text { heksan }\end{array}$ & $\begin{array}{c}\text { Air : metanol } \\
(95: 5)\end{array}$ & $\begin{array}{l}\text { Amonium format: } \\
\text { metanol }\end{array}$ & $\begin{array}{l}\text { Isokratik, } \\
\text { 70:30 }\end{array}$ & $1 \mathrm{~mL} / \mathrm{min}$ & $\begin{array}{l}\text { Puncak AMOZ } \\
\text { tampak pecah } \\
\text { (split peak) }\end{array}$ \\
\hline $\begin{array}{l}\text { Alkan dkk. } \\
(2016), \\
\text { dengan } \\
\text { penyesuaian }\end{array}$ & $\begin{array}{c}5 \mathrm{~mL} \text { etil asetat } \\
+3 \mathrm{~mL} \mathrm{n}- \\
\text { heksan }\end{array}$ & $\begin{array}{c}\text { Air : metanol } \\
(95: 5)\end{array}$ & $\begin{array}{l}\text { Amonium asetat: } \\
\text { metanol }\end{array}$ & $\begin{array}{l}\text { Isokratik, } \\
\text { 70:30 }\end{array}$ & $0,5 \mathrm{~mL} / \mathrm{min}$ & $\begin{array}{c}\text { Semua analit } \\
\text { dapat terpisah } \\
\text { dan memiliki } \\
\text { profil puncak } \\
\text { yang cukup baik }\end{array}$ \\
\hline
\end{tabular}

Sebelum melakukan validasi metode, terlebih dahulu dilakukan uji kesesuaian sistem terhadap sistem kromatografi. Hal ini dilakukan dengan menyuntikkan satu konsentrasi larutan baku ke dalam sistem KCKT dengan kondisi analisis terpilih, dengan pengulangan sebanyak enam kali (Shabir, 2003). Parameter yang diuji antara lain faktor retensi (k'), keterulangan waktu retensi dan area puncak (dinyatakan dengan \%RSD), resolusi (Rs), tailing factor (T), dan angka lempeng teoritis $(\mathrm{N})$. Hasil uji kesesuaian sistem pada penelitian ini dapat dilihat pada Tabel 2.

Tabel 2. Hasil uji kesesuaian sistem KCKT pada kondisi terpilih*)

\begin{tabular}{ccccccc}
\hline Analit & $\begin{array}{c}\text { \%RSD } \\
\text { Rt }\end{array}$ & $\begin{array}{c}\text { \%RSD } \\
\text { Area }\end{array}$ & $\begin{array}{c}\text { Rerata } \\
k^{\prime}\end{array}$ & $\begin{array}{c}\text { Rerata } \\
\text { Resolusi }\end{array}$ & Rerata $T$ & Rerata $N$ \\
\hline AOZ & 0,08 & 1,71 & 4,79 & 2,52 & 1,13 & 15357,32 \\
AMOZ & 0,11 & 0,32 & 5,38 & 3,22 & 1,10 & 20167,10 \\
AHD & 0,08 & 0,28 & 2,78 & 4,08 & 1,66 & 11852,76 \\
Syarat & $\leq 1$ & $\leq 1$ & $>2$ & $>2$ & $\leq 2$ & $>2000$ \\
$\begin{array}{l}\text { Keberterimaan } \\
\text { (Shabir, 2003) }\end{array}$ & & & & \\
*)Fase gerak ammonium asetat : asetonitril (70:30), laju alir $0,5 \mathrm{~mL} /$ menit, volume injeksi \\
$100 \mu \mathrm{L}$, panjang gelombang $260 \mathrm{~nm}$.
\end{tabular}

Analisis metabolit nitrofuran dilakukan dengan cara derivatisasi dalam suasana asam. Proses derivatisasi menggunakan 2-nitrobenzaldehida dilakukan melalui inkubasi selama 16 jam pada suhu $37^{\circ} \mathrm{C}$. Kemudian dilakukan ekstraksi menggunakan campuran etil asetat dan n-heksana, setelah itu hasil ekstraksi dikeringkan. Ekstrak kering dilarutkan kembali dengan n-heksana, kemudian ditambahkan larutan methanol : air (5:95) dan dikocok menggunakan mixer. Fase air inilah yang diambil dan disuntikkan ke system KCKT.

Uji selektivitas dilakukan untuk mengetahui apakah suatu metode dapat memisahkan analit dari senyawa pengotor, matriks atau degradan. Puncak kromatogram analit tidak boleh diganggu oleh puncak-puncak komponen lain, dan memberikan pemisahan yang baik antara analit dengan komponen lain (matriks, pengotor, degradan). Persyaratan agar suatu metode dapat disebut selektif adalah resolusi lebih besar dari 1,5 (Yuwono \& Indrayanto, 2005). Hasil dari uji selektivitas dapat dilihat pada Gambar 2 dan Gambar 3. Uji resolusi ini menunjukkan keterpisahan AOZ, AMOZ, dan AHD dari satu sama lain dan juga keterpisahan ketiga analit tersebut dari puncak lain dalam matriks sampel. Pada Gambar 4, dapat dilihat bahwa resolusi AOZ, AMOZ dan AHD masing-masing adalah 12,62; 3,31; dan 4,28. Sehingga dapat disimpulkan bahwa tiap analit memiliki keterpisahan yang baik dan memenuhi syarat keberterimaan. 


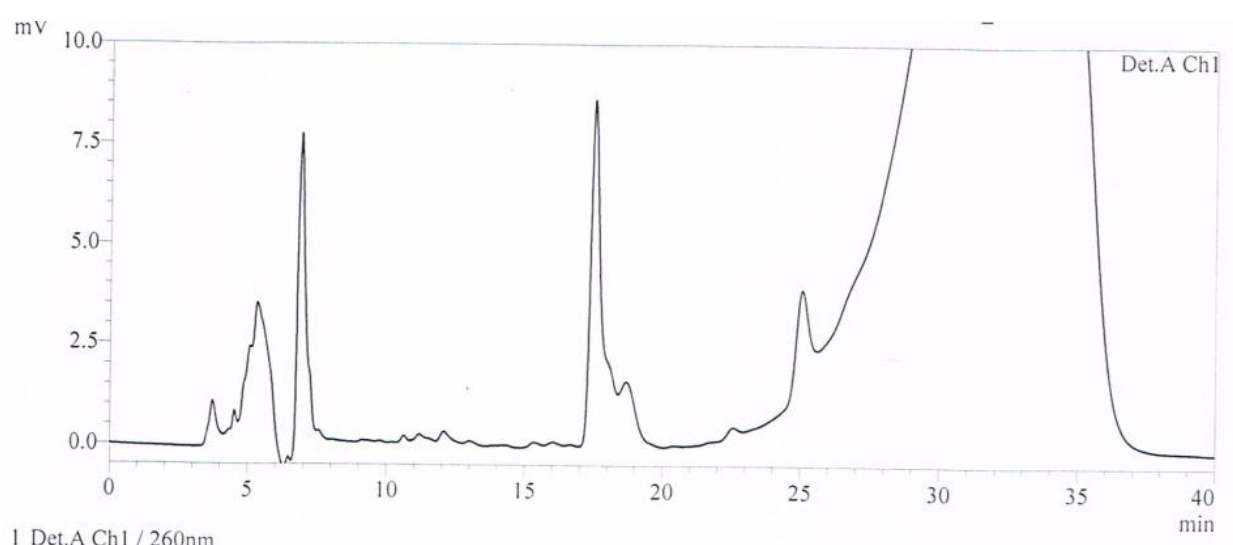

1 Det.A Chl $/ 260 \mathrm{~nm}$

Gambar 2. Kromatogram matriks sampel

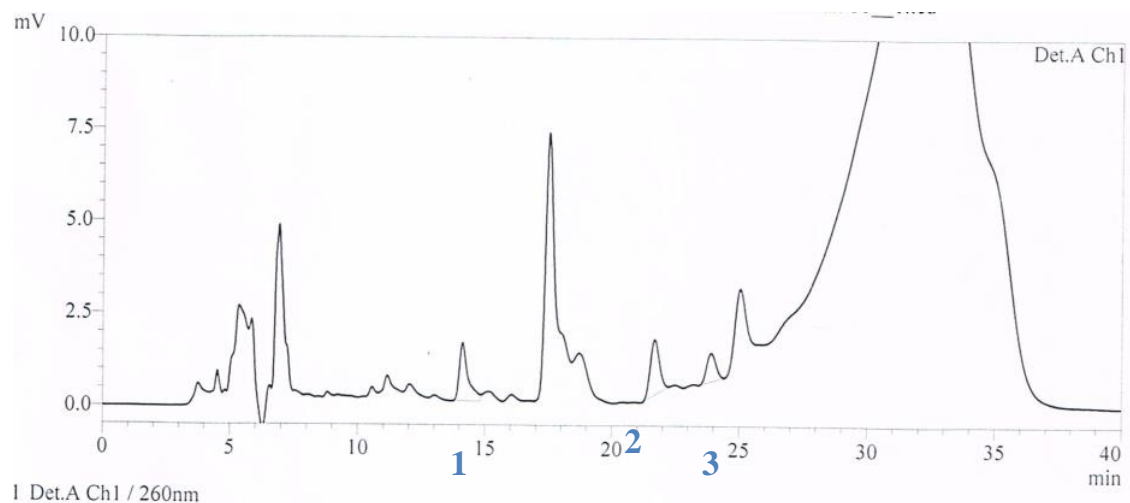

Gambar 3. Kromatogram analit pada uji selektivitas: 1) AHD; 2) AOZ; 3) AMOZ (konsentrasi: AOZ 83,03 ng/mL; AMOZ 90,13 ng/mL; AHD 79,87 ng/mL).

Resolusi analit: AOZ 12,62; AMOZ 3,31; AHD 4,28

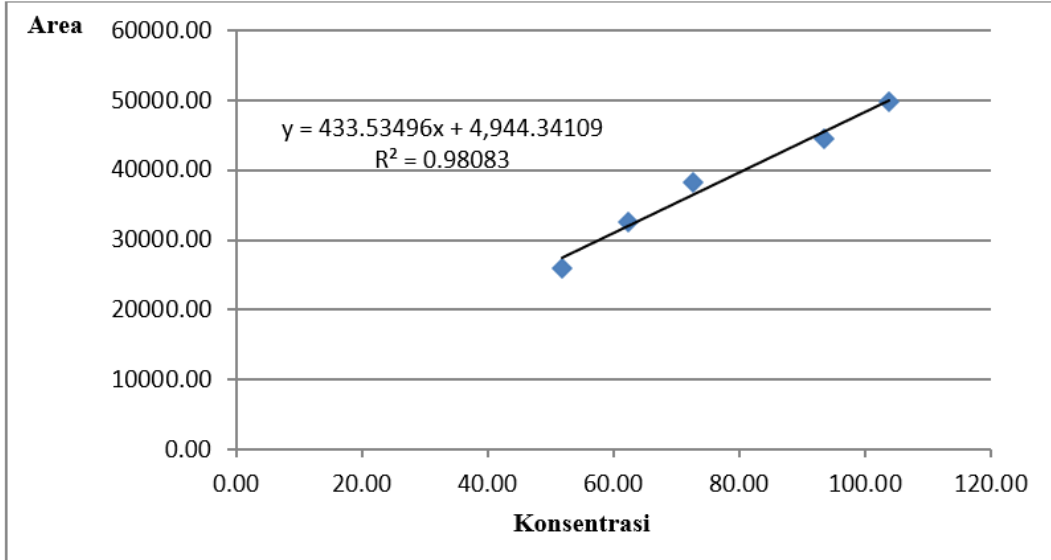

Gambar 4. Kurva baku AOZ pada rentang konsentrasi 51,90 - 103,79 ng/mL

Uji linieritas dilakukan dengan membuat kurva baku. Larutan baku campuran dalam matriks sampel dibuat dengan rentang konsentrasi AOZ, AMOZ, dan AHD masing-masing adalah 51,90 - 103,79 ng/mL; 56,63 - 101,39 ng/mL; dan 49,92 - 89,86 ng/mL. Dari kromatogram yang didapat, dibuat kurva baku antara area puncak dengan konsentrasi baku, kemudian dihitung harga koefisien korelasi ( $\mathrm{r}$ ) dan persamaan $\mathrm{y}=$ $a+b x$. Persamaan regresi dianggap linier jika $r \geq 0,999$ dan nilai $\mathrm{V}_{\mathrm{xo}}$ tidak boleh lebih dari 5\% (Yuwono and Indrayanto, 2005). Kurva baku masing-masing analit dapat dilihat pada Gambar 4, Gambar 5 dan Gambar 6, sedangkan parameter keberterimaan (koefisien korelasi dan nilai $\mathrm{V}_{\mathrm{x} 0}$ ) tercantum pada Tabel 3. Dari Gambar 4, Gambar 5 dan Gambar 6 serta Tabel 3, terlihat koefisien korelasi AOZ dan AHD serta nilai $\mathrm{V}_{\mathrm{x} 0}$ AHD tidak memenuhi syarat keberterimaan. 
Tabel 3. Validitas metode analisis

\begin{tabular}{cccc}
\hline Parameter & \multicolumn{3}{c}{ Analit } \\
\cline { 2 - 4 } & AOZ & AMOZ & AHD \\
\hline Koefisien korelasi $(\mathrm{r})$ & 0,99037 & 0,99977 & 0,97963 \\
$\mathrm{~V}_{\mathrm{x} 0}(\%)$ & 4,52 & 0,66 & 5,35 \\
Rekoveri $(\%)$ & $78,50-102,29$ & $77,02-99,87$ & $85,54-99,77$ \\
RSD $(\%)$ & $6,10-19,90$ & $3,68-17,75$ & $2,75-12,58$ \\
LOD $(\mathrm{ng} / \mathrm{mL})$ & 3,09 & 6,84 & 4,61 \\
LOQ $(\mathrm{ng} / \mathrm{mL})$ & 10,29 & 22,82 & 15,36 \\
\hline
\end{tabular}

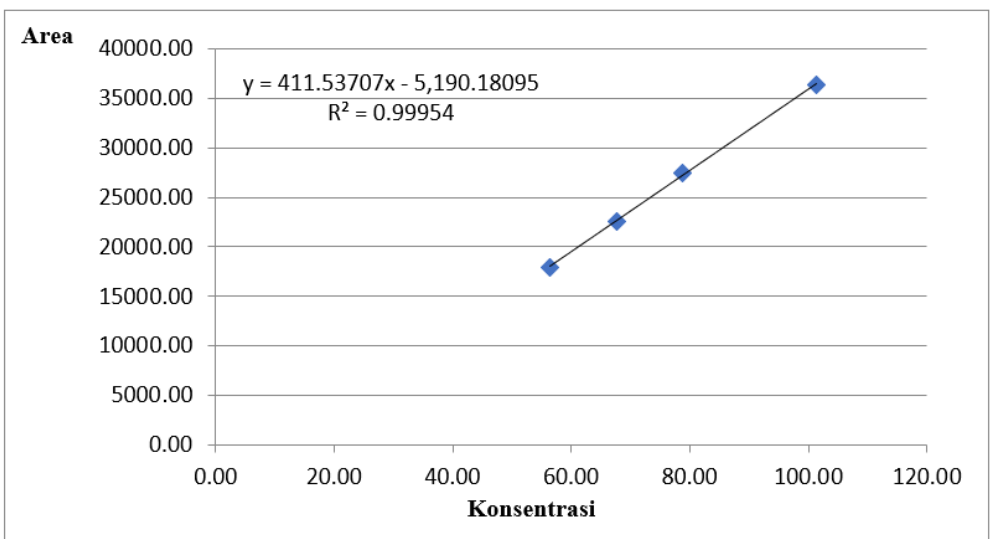

Gambar 5. Kurva baku AMOZ pada rentang konsentrasi 56,63 - 101,39 ng/mL

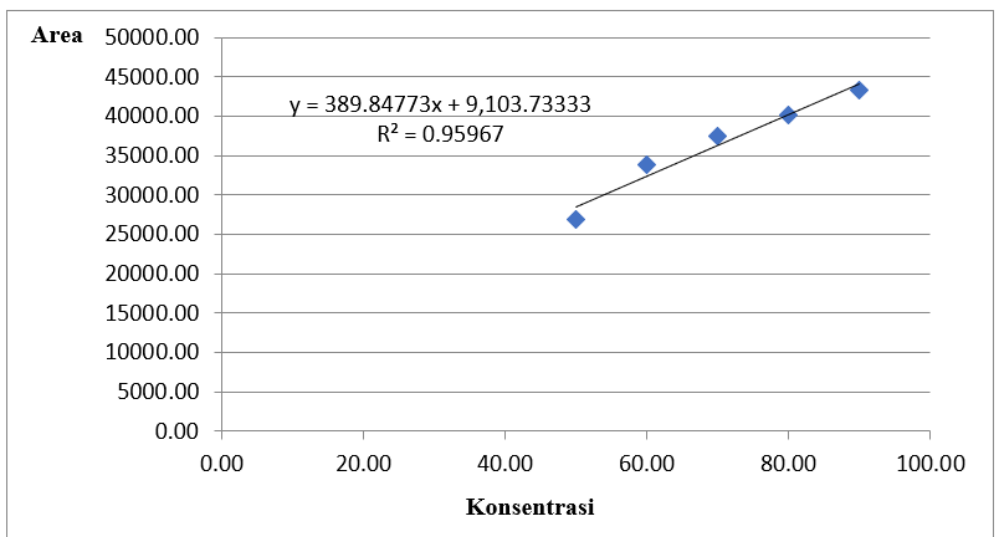

Gambar 6. Kurva baku AHD pada rentang konsentrasi 49,92 - 89,86 ng/mL

Akurasi dinyatakan sebagai persen rekoveri dari hasil analisis uji terhadap kadar analit sebenarnya yang ditambahkan dalam masing-masing sampel. Pembuatan larutan uji akurasi dilakukan dengan cara menyiapkan sampel bakso udang yang ditambah dengan larutan baku antara campuran $1 \mu \mathrm{g} / \mathrm{mL}$ sebanyak 0,$24 ; 0,32$; dan 0,4 $\mathrm{mL}$ dengan replikasi sebanyak tiga kali untuk setiap konsentrasi, kemudian dihitung persen rekoveri dan standar deviasinya. Hasilnya dapat dilihat pada Tabel 3. Menurut AOAC (2016), syarat keberterimaan rekoveri untuk analit dengan kadar 10 - 100 ng/mL adalah 60 $115 \%$. Dari hasil yang diperoleh, dapat dilihat bahwa rekoveri ketiga analit memenuhi kriteria.

Uji presisi yang dilakukan pada penelitian ini adalah repeatability, yaitu analisis dengan replikasi tiga

P-ISSN: 2406-9388

E-ISSN: 2580-8303 kali secara independen dari tiga konsentrasi sampel seperti pada uji akurasi. Kriteria penerimaan presisi adalah dengan menghitung nilai relative standard deviation (RSD). Untuk AOZ, AMOZ, dan AHD pada penelitian ini, syarat keberterimaan RSD pada kadar analit 10-100 ng/mL adalah 21\% (AOAC, 2016). Sebagaimana dapat dilihat pada Tabel 3, bahwa semua analit memenuhi kriteria.

Penentuan LOD dan LOQ dilakukan dengan cara menghitung rasio signal-to-noise. Disuntikkan larutan baku dengan konsentrasi lebih rendah daripada larutan baku terkecil pada uji linieritas. Hasil LOD dan LOQ penelitian ini dapat dilihat pada Tabel 3, dan dapat disimpulkan bahwa metode yang digunakan dapat 
mendeteksi analit dalam konsentrasi lebih rendah daripada rentang linieritas.

Hasil dari serangkaian uji yang telah dilakukan menunjukkan bahwa metode ini masih memerlukan penyempurnaan, terutama untuk linieritas AHD. Untuk keperluan skrining analit, parameter utama adalah selektivitas dan LOD serta LOQ. Dengan melihat hasil uji selektivitas, LOD dan LOQ pada penelitian ini yang semuanya memenuhi kriteria keberterimaan, maka metode ini dapat digunakan untuk skrining cemaran AOZ, AMOZ dan AHD dalam produk olahan udang.

\section{KESIMPULAN}

Dari penelitian yang telah dilakukan, dapat disimpulkan bahwa metode analisis metabolit nitrofuran secara KCKT dengan fase gerak ammonium asetat $20 \mathrm{mM}$ : asetonitril (70:30), laju alir 0,5 mL/menit dan panjang gelombang $260 \mathrm{~nm}$ ini dapat digunakan sebagai metode skrining cemaran metabolit nitrofuran (AOZ, AMOZ, AHD) dalam produk olahan udang.

\section{UCAPAN TERIMA KASIH}

Penulis mengucapkan terimakasih kepada Badan Pengawas Obat dan Makanan dan khususnya Balai Besar Pengawas Obat dan Makanan di Surabaya atas kesempatan dan fasilitas yang diberikan.

\section{DAFTAR PUSTAKA}

Aldeek, F., Hsieh, K. C., Ugochukwu, O. N., Gerard, G. \& Hammack, W. (2018). Accurate Quantitation and Analysis of Nitrofuran Metabolites, Chloramphenicol, and Florfenicol in Seafood by Ultrahigh-Performance Liquid ChromatographyTandem Mass Spectrometry: Method Validation and Regulatory Samples [Research-article]. Journal of Agricultural and Food Chemistry; 66; 5018-5030.

Alkan, F., Kotan, A. \& Ozdemir, N. (2016). Development and Validation of Confirmatory Method for Analysis of Nitrofuran Metabolites in Milk, Honey, Poultry Meat and Fish by Liquid Chromatography-Mass Spectrometry. Macedonian Veterinary Review; 39; 15-22.

AOAC. (2016). Appendix F: Guidelines for Standard Method Performance Requirements. Rockville: AOAC International.

Aydin, S. (2015). A Short History, Principles, and Types of ELISA, and Our Laboratory Experience with Peptide/Protein Analyses Using ELISA. Peptides; 72; 4-15.
European Comission. (2007). The Rapid Alert System for Food and Feed (RASFF) Annual Report 2007. Luxembourg: Office for Official Publications of the European Communities.

Fernando, R., Munasinghe, D. M. S., Gunasena, A. R. C. \& Abeynayake, P. (2017). Determination of Nitrofuran Metabolites in Shrimp Muscle by Liquid Chromatography-Photo Diode Array Detection. Food Control; 72; 300-305.

Kaufmann, A., Butcher, P., Maden, K., Walker, S. \& Widmer, M. (2015). Determination of Nitrofuran and Chloramphenicol Residues by High Resolution Mass Spectrometry Versus Tandem Quadrupole Mass Spectrometry. Analytica Chimica Acta; 862; 41-52.

Khong, S. P., Gremaud, E., Richoz, J., Delatour, T., Guy, P. A., Stadler, R. H. \& Mottier, P. (2004). Analysis of Matrix-Bound Nitrofuran Residues in Worldwide-Originated Honeys by Isotope Dilution High-Performance Liquid Chromatography-Tandem Mass Spectrometry. Journal of Agricultural and Food Chemistry; 52; 5309-5315.

Prihanani, N. I., Nugroho, W. S. \& Wijayanti, A. D. (2017). Analisis Residu 3-amino-2-oxazolidinone (AOZ) pada Hati dan Otot Dada Ayam Setelah Proses Pemanasan menggunakan Metode Kromatografi Cair Kinerja Tinggi (KCKT). Tesis; Fakultas Kedokteran Hewan Universitas Gadjah Mada, Yogyakarta.

Shabir, G. A. (2003). Validation of High-Performance Liquid Chromatography Methods for Pharmaceutical Analysis. Journal of Chromatography A; 987; 57-66.

Vass, M., Hruska, K. \& Franek, M. (2008). Nitrofuran Antibiotics: A Review on the Application, Prohibition and Residual Analysis. Veterinarni Medicina; 53; 469-500.

Verdon, E., Couedor, P. \& Sanders, P. (2007). MultiResidue Monitoring for the Simultaneous Determination of Five Nitrofurans (Furazolidone, Furaltadone, Nitrofurazone, Nitrofurantoine, Nifursol) in Poultry Muscle Tissue Through the Detection of Their Five Major Metabolites (AOZ, AMOZ, SEM, AHD, DNSA. Analytica Chimica Acta; 586; 336-347.

Yuwono, M., \& Indrayanto, G. (2005). Validation of Chromatographic Methods of Analysis. Profiles of Drug Substances, Excipients and Related Methodology; 32; 241-260. 